\title{
PENGARUH PROGRAM KESELAMATAN DAN KESEHATAN KERJA (K3), LINGKUNGAN KERJA, SERTA KOMITMEN ORGANISASIONAL TERHADAP KINERJA PEGAWAI
}

\author{
Komang Hans Jayaputra ${ }^{1}$ \\ Anak Agung Ayu Sriathi ${ }^{2}$ \\ 1,2 Fakultas Ekonomi dan Bisnis Universitas Udayana (Unud), Bali, Indonesia \\ email: komanghans7@gmail.com
}

\begin{abstract}
ABSTRAK
Kinerja merupakan pencapaian atas hasil kerja karyawan berdasarkan kualitas maupun kuantitas sebagai prestasi kerja dalam periode waktu tertentu yang disesuaikan dengan tugas dan tanggung jawabnya. Kinerja pegawai dapat diukur dalam beberapa hal yaitu pelaksanaan keselamatan kesehatan kerja (K3), lingkungan kerja dan komitmen organisasional. Penelitian ini dilakukan dengan tujuan untuk menganalisis pengaruh keselamatan dan kesehatan kerja (K3), lingkungan kerja dan komitmen organisasional terhadap kinerja karyawan pada pegawai di BPBD Provinsi Bali. Seluruh pegawai pelaksana BPBD Provinsi Bali yang berjumlah 50 orang dalam penelitian ini digunakan sebagai sampel, sehingga teknik pengambilan sampel menggunakan sampel jenuh. Analisis yang digunakan terdiri dari analisis statistik deskriptif, uji asumsi klasik dan analisis regresi linier berganda. Hasil analisis menunjukkan bahwa keselamatan dan kesehatan kerja (K3), lingkungan kerja dan komitmen organisasional berpengaruh positif dan signifikan terhadap kinerja pegawai di BPBD Provinsi Bali. Hal ini menunjukan bahwa semakin baik pelaksanaan program keselamatan dan kesehatan kerja yang diterapkan oleh pegawai, kemudian semakin baik kondisi lingkungan kerja pada BPBD Provinsi Bali dan semakin tinggi komitmen organisasional yang dimiliki pegawai BPBD Provinsi Bali, maka akan semakin tinggi pula kinerja yang ditunjukkan oleh pegawai.

Kata Kunci : keselamatan dan kesehatan kerja (K3), lingkungan kerja, komitmen organisasional, kinerja karyawan
\end{abstract}

\begin{abstract}
Performance is the achievement of the work of employees based on quality and quantity as work performance in a certain period of time that is adjusted to the duties and responsibilities. Employee performance can be measured in several ways, namely the implementation of occupational health safety (K3), work environment and organizational commitment. This research was conducted with the aim of analyzing the effect of occupational safety and health (K3), work environment and organizational commitment to employee performance on employees in BPBD Province of Bali. All 50 BPBD implementing staff in Bali in this study were used as samples, so the sampling technique used saturated samples. The analysis used consists of descriptive statistical analysis, classic assumption tests and multiple linear regression analysis. The analysis showed that occupational safety and health (K3), work environment and organizational commitment had a positive and significant effect on employee performance in the BPBD of the Province of Bali. This shows that the better the implementation of occupational safety and health programs implemented by employees, the better the working environment conditions in BPBD Bali Province and the higher organizational commitment that BPBD Bali Province employees have, the higher the performance shown by employees.

Keywords: occupational safety and health (K3), work environment, organizational commitment, employee performance
\end{abstract}




\section{PENDAHULUAN}

Undang-Undang Dasar 1945 pasal 27 ayat 2 menetapkan bahwa setiap warga negara berhak atas pekerjaan dan penghidupan yang layak bagi kemanusiaan. Yang dimaksud dengan pekerjaan dan penghidupan yang layak adalah pekerjaan yang bersifat manusiawi, yang memungkinkan pekerja berada dalam kondisi selamat dan sehat, bebas dari kecelakaan dan penyakit akibat kerja serta lingkungan kerja yang aman, nyaman dan tentram sewaktu bekerja. Indonesia memiliki tantangan yang cukup besar dalam menyikapi keadaan geografis wilayahnya. Berdasarkan hal tersebut berbagai daerah di Indonesia memiliki ancaman terhadap terjadinya suatu bencana. Indonesia juga dikenal sebagai negara paling rawan bencana dibandingkan dengan negara lainnya di dunia.

Menurut suatu Badan PBB yang membidangi resiko bencana yaitu UNISDR (United Nations International Strategy for Disaster Reduction), Indonesia menduduki peringkat teratas untuk beberapa jenis bencana alam yang dilihat dari korban meninggal dunia akibat bencana tersebut, dapat diartikan bahwa kesiapsiagaan bencana di Indonesia masih tergolong rendah dibandingkan negara lainnya di dunia. Maka dari itu, pencegahan dan kesiapsiagaan pegawai Badan Penanggulangan Bencana Daerah (BPBD) harus ditingkatkan, khususnya di Provinsi Bali.

Bencana yang terjadi di Provinsi Bali tidak dapat diprediksi tingkat kejadiannya. Dalam pelaksanaannya tentu saja terdapat kendala sehingga hasil yang diinginkan belum maksimal. Maka dari itu, dalam manajemen pemerintahan di BPBD Provinsi Bali, perlu melakukan suatu evaluasi kinerja. Dimana selanjutnya akan menimbulkan pertanyaan bagaimana sebenarnya keberhasilan BPBD dalam pelaksanaan bidang pencegahan dan kesiapsiagaan bencana.

Salah satu faktor yang mempengaruhi tingkat keberhasilan suatu organisasi atau perusahaan adalah sumber daya manusia. Peran karyawan sangat besar dalam mencapai keberhasilan perusahaan, hal yang perlu dipertimbangkan adalah performance karyawan yaitu pelayanan. Keberhasilan suatu perusahaan ditentukan oleh pelayanan yang diberikan. Kinerja karyawan adalah salah satu faktor yang mempengaruhi tingkat keberhasilan suatu organisasi atau perusahaan. Kinerja karyawan merupakan suatu tindakan yang dilakukan karyawan dalam melaksanakan pekerjaan yang diberikan perusahan (Handoko, 2017:135).

Rivai \& Sagala (2014:547) menyatakan bahwa didalam dunia usaha berkompetisi secara global, perusahaan memerlukan kinerja tinggi. Kinerja merupakan pencapaian atas hasil kerja karyawan berdasarkan kualitas maupun kuantitas sebagai prestasi kerja dalam periode waktu tertentu yang disesuaikan dengan tugas dan tanggung jawabnya (Mangkunegara, 2013:9). Kinerja pegawai dapat diukur dalam beberapa hal yaitu pelaksanaan keselamatan kesehatan kerja (K3), lingkungan kerja dan komitmen organisasional. Penelitian Kautsar et al. (2013) menyatakan bahwa keselamatan kesehatan kerja, dan lingkungan kerja berpengaruh positif dan signifikan terhadap kinerja pegawai.

Badan Penanggulangan Bencana (BPBD) Provinsi Bali perlu memahami kondisi pegawai, apa yang menjadi penyebab menurunnya kinerja pegawai. Hasil wawancara dan observasi yang dilakukan pada petugas Badan Penanggulangan Bencana Daerah (BPBD) Provinsi Bali mengindikasikan bahwa terdapat 
permasalahan terkait kinerja pegawai. Permasalahan tersebut baik dilihat dari indikator kurang optimalnya kinerja pegawai Badan Penanggulangan Bencana Daerah (BPBD) Provinsi Bali dari segi lingkungan kerja fisik dan non fisik yaitu beberapa pegawai mengeluh tentang lingkungan kerja yang kurang memadai seperti peralatan dan perlengkapan yang kurang dan rusak.

Contoh pada bencana alam gunung agung ada beberapa handy talkie (HT) yang bermasalah dan rusak sehingga membuat kinerja pegawai pelaksana sedikit terhambat dalam pemberian informasi dan komunikasi, ada pun pegawai yang mengalami kecelakaan kerja di gigit ular, jatuh dari pohon, kulit terbakar karena menolong korban kebakaran mereka menginginkan selain keselamatan mereka di tanggung oleh tempat mereka bekerja mereka juga ingin di perhatikan oleh atasan setidaknya menjenguk ke rumah sakit atau memberikan sedikit perhatian saat mengalami kecelakaan kerja.

Berkaitan dengan hal tersebut perlu adanya perhatian yang lebih dari Badan Penanggulangan Bencana Daerah (BPBD) Provinsi Bali. Dengan melihat tidak optimalnya para pegawai, mengindikasikan bahwa ada permasalahan yang terjadi pada kinerja pegawai BPBD Provinsi Bali. Badan Penanggulangan Bencana Daerah (BPBD) Provinsi Bali merupakan tanggung jawab langsung kepala dinas yang bertugas untuk melakukan penanganan kebencanaan daerah Bali seperti gunung meletus, banjir, kebakaran dan lain sebagainya. Petugas pelaksana Badan Penanggulangan Bencana (BPBD) Provinsi Bali memiliki resiko kerja yang lebih tinggi di bandingkan dengan pegawai BPBD lainnya sehingga rentan akan kinerja mereka. Oleh karena itu kinerja petugas pelaksana perlu di perhatikan dan faktor apa yang menyebabkan kinerja petugas pelaksana Badan Penanggulangan Bencana Daerah (BPBD) Provinsi Bali kurang optimal. Terdapat banyak faktor yang dapat mempengaruhi kinerja pegawai diantaranya yaitu rasa aman dan nyaman dalam bekerja dan kompensasi yang ada dalam institusi terkait (Nitisemito, 2011:109).

Program keselamatan kesehatan kerja (K3) yang memadai membuat petugas pelaksana Badan Penanggulangan Bencana Daerah (BPBD) Provinsi Bali merasa aman dan nyaman dalam melaksanakan tugas, berpengaruh terhadap kualitas dan kuantitas kerja mereka meningkat sehingga kinerja mereka dapat lebih optimal. Keselamatan dan kesehatan kerja (K3) memiliki peran penting dalam meningkatkan kinerja pegawai pelaksana Badan Penanggulangan Bencana Daerah (BPBD) Provinsi Bali. Keselamatan dan kesehatan kerja merupakan salah satu cara untuk melindungi para karyawan dari bahaya kecelakaan kerja dan penyakit akibat pekerjaan (Maduka \& Okafor, 2014). Menurut Tsenawatme (2013) keselamatan dan kesehatan kerja (K3) berpengaruh positif dan signifikan terhadap kinerja pegawai. Keselamatan dan kesehatan kerja (K3) diatur dalam undang-undang ketenagakerjaan pasal 86 sampai dengan 87 . Faktanya masih kurang perusahaan maupun instansi yang sadar akan pentingnya keselamatan dan kesehatan kerja (K3) yang merupakan salah satu faktor yang dapat menghambat pekerjaan perusahaan. Kasus kecelakan kerja yang terjadi pada Badan Penanggulangan Bencana Daerah (BPBD) Provinsi Bali terdiri dari kecelakaan kerja ringan maupun berat. 
Tabel 1.

.Kasus Kecelakaan Kerja BPBD Provinsi Bali

\begin{tabular}{cc}
\hline Tahun & Kasus \\
\hline 2017 & 20 \\
2018 & 22 \\
2019 & 14 \\
\hline Sumber: Sub Baging
\end{tabular}

Sumber: Sub Bagian Umum Badan Penanggulangan Bencana Daerah (BPBD) Provinsi Bali (2019)

Tanpa sumber daya manusia, sumber daya lainnya menganggur dan kurang bermanfaat dalam mencapai tujuan organisasi. Peran karyawan sangat besar dalam mencapai keberhasilan perusahaan, hal yang perlu dipertimbangkan adalah performance karyawan yaitu pelayanan. Keberhasilan suatu perusahaan ditentukan oleh pelayanan yang diberikan. Setiap perusahaan tentu selalu meningkatkan performance karyawannya, dengan harapan tujuan perusahaan juga tercapai (Sugiyono, 2017:76). Kinerja karyawan adalah salah satu faktor yang mempengaruhi tingkat keberhasilan suatu organisasi atau perusahaan. Kinerja karyawan merupakan suatu tindakan yang dilakukan karyawan dalam melaksanakan pekerjaan yang diberikan perusahan (Handoko, 2017:135).

Rivai \& Sagala (2014:547) menyatakan bahwa didalam dunia usaha berkompetisi secara global, perusahaan memerlukan kinerja tinggi. Kinerja merupakan pencapaian atas hasil kerja karyawan berdasarkan kualitas maupun kuantitas sebagai prestasi kerja dalam periode waktu tertentu yang disesuaikan dengan tugas dan tanggung jawabnya (Mangkunegara, 2013:9). Kinerja pegawai dapat diukur dalam beberapa hal yaitu pelaksanaan keselamatan kesehatan kerja (K3), lingkungan kerja dan komitmen organisasional. Penelitian Kautsar et al. (2013) menyatakan bahwa keselamatan kesehatan kerja, dan lingkungan kerja berpengaruh positif dan signifikan terhadap kinerja pegawai dan penelitian yang dilakukan Katua et al. (2014) bahwa komitmen organisasi memiliki efek yang positif dan signifikan terhadap kinerja pegawai.

Menurut Supriyadi (2010) peningkatan kinerja dapat dilihat dalam tiga bentuk yaitu jumlah produksi meningkat dengan menggunakan sumber daya yang sama, jumlah produksi yang sama atau meningkat dicapai dengan menggunakan sumber daya yang lebih sedikit dan jumlah produksi jauh lebih besar diperoleh dengan pertambahan sumber daya yang relatif lebih besar. Kinerja yang tinggi diharapkan memberikan kontribusi signifikan terhadap kinerja dan kemampuan perusahaan, karena kinerja perusahaan merupakan sinergi dari seluruh karyawan dan kinerja seluruh tim unit perusahaan (Darmanegara, 2013). Badan Penanggulangan Bencana (BPBD) Provinsi Bali perlu memahami kondisi pegawai, apa yang menjadi penyebab menurunnya kinerja pegawai. Hasil wawancara dan observasi yang dilakukan pada petugas Badan Penanggulangan Bencana Daerah (BPBD) Provinsi Bali mengindikasikan bahwa terdapat permasalahan terkait kinerja pegawai. Permasalahan tersebut baik dilihat dari indikator kurang optimalnya kinerja pegawai Badan Penanggulangan Bencana Daerah (BPBD) Provinsi Bali dari segi lingkungan kerja fisik dan non fisik yaitu beberapa pegawai mengeluh tentang lingkungan kerja yang kurang memadai seperti peralatan dan perlengkapan yang kurang dan rusak. 
Contoh pada bencana alam gunung agung ada beberapa handy talkie (HT) yang bermasalah dan rusak sehingga membuat kinerja pegawai pelaksana sedikit terhambat dalam pemberian informasi dan komunikasi, ada pun pegawai yang mengalami kecelakaan kerja di gigit ular, jatuh dari pohon, kulit terbakar karena menolong korban kebakaran mereka menginginkan selain keselamatan mereka di tanggung oleh tempat mereka bekerja mereka juga ingin di perhatikan oleh atasan setidaknya menjenguk ke rumah sakit atau memberikan sedikit perhatian saat mengalami kecelakaan kerja.

Berkaitan dengan hal tersebut perlu adanya perhatian yang lebih dari Badan Penanggulangan Bencana Daerah (BPBD) Provinsi Bali. Dengan melihat tidak optimalnya para pegawai, mengindikasikan bahwa ada permasalahan yang terjadi pada kinerja pegawai BPBD Provinsi Bali. Badan Penanggulangan Bencana Daerah (BPBD) Provinsi Bali merupakan tanggung jawab langsung kepala dinas yang bertugas untuk melakukan penanganan kebencanaan daerah Bali seperti gunung meletus, banjir, kebakaran dan lain sebagainya. Petugas pelaksana Badan Penanggulangan Bencana (BPBD) Provinsi Bali memiliki resiko kerja yang lebih tinggi di bandingkan dengan pegawai BPBD lainnya sehingga rentan akan kinerja mereka. Oleh karena itu kinerja petugas pelaksana perlu di perhatikan dan faktor apa yang menyebabkan kinerja petugas pelaksana Badan Penanggulangan Bencana Daerah (BPBD) Provinsi Bali kurang optimal. Terdapat banyak faktor yang dapat mempengaruhi kinerja pegawai diantaranya yaitu rasa aman dan nyaman dalam bekerja dan kompensasi yang ada dalam institusi terkait (Nitisemito, 2011:109).

Program keselamatan kesehatan kerja (K3) yang memadai membuat petugas pelaksana Badan Penanggulangan Bencana Daerah (BPBD) Provinsi Bali merasa aman dan nyaman dalam melaksanakan tugas. Berpengaruh terhadap kualitas dan kuantitas kerja mereka meningkat sehingga kinerja mereka dapat lebih optimal. Keselamatan dan kesehatan kerja (K3) merupakan salah satu masalah yang signifikan sehubung dengan pencapaian tujuan suatu organisasi (Akpan, 2011). Keselamatan dan kesehatan kerja (K3) memiliki peran penting dalam meningkatkan kinerja pegawai pelaksana Badan Penanggulangan Bencana Daerah (BPBD) Provinsi Bali. Keselamatan dan kesehatan kerja merupakan salah satu cara untuk melindungi para karyawan dari bahaya kecelakaan kerja dan penyakit akibat pekerjaan (Maduka \& Okafor, 2014). Wibowo \& Utomo (2016) mengutarakan di tempat kerja manapun keselamatan karyawan harus menjadi prioritas baik seseorang yang bekerja dalam pekerjaan beresiko tinggi maupun rendah. Keselamatan dan kesehatan kerja (K3) ditempat kerja sangat penting untuk memastikan bahwa organisasi menyediakan lingkungan yang aman bagi perusahaan karyawan dan untuk meminimalkan resiko kecelakaan dan cedera (Machabe \& Indermun, 2013). Menurut Tsenawatme (2013) keselamatan dan kesehatan kerja (K3) berpengaruh positif dan signifikan terhadap kinerja pegawai. Keselamatan dan kesehatan kerja (K3) diatur dalam undang-undang ketenagakerjaan pasal 86 sampai dengan 87. Faktanya masih kurang perusahaan maupun instansi yang sadar akan pentingnya keselamatan dan kesehatan kerja (K3) yang merupakan salah satu faktor yang dapat menghambat pekerjaan perusahaan. Kasus kecelakan kerja yang terjadi pada Badan Penanggulangan Bencana Daerah (BPBD) Provinsi Bali terdiri dari kecelakaan kerja ringan maupun berat. 
Lingkungan kerja merupakan sebuah tempat atau kantor yang menjadi faktor eksternal yang dapat mempengaruhi kinerja kerja pegawai. Lingkungan kerja yang baik dapat menciptakan hubungan kerja yang mengikat antara orang-orang yang ada di dalam lingkungannya. Lingkungan kerja adalah sesuatu yang ada dilingkungan para pekerja yang dapat mempengaruhi dirinya dalam menjalankan tugas seperti suasana nyaman dalam kantor maupun tugas lapangan, akses internet terjangkau, rekan kerja yang ramah, kebersihan tempat kerja, dan alat-alat perlengkapan kerja. Lingkungan kerja merupakan salah satu faktor yang mempunyai dampak positif terhadap kinerja pegawai (Nuraini, 2013:97).

Lingkungan kerja yang baik dalam hal ini penyediaan sarana dan prasarana yang memadai atau buruk tidaknya ketersedian sarana dan prasarana penunjang dalam bekerja secara langsung ataupun tidak langsung akan dapat mempengaruhi semangat dan kegairahan karyawan dalam bekerja (Roharto \& Kasmir, 2017). Almeida et al. (2019) mengutarakan lingkungan kerja yang baik merupakan salah satu hal yang menyebabkan, menyalurkan, mendukung perilaku manusia supaya mau bekerja giat dan antusias mencapai hasil yang maksimal. Lingkungan kerja yang baik merupakan salah satu usaha pemeliharaan karyawan yang sangat penting untuk mempertahankan karyawan yang berkualitas dan memiliki kinerja tinggi (Priarso, 2018).

Dengan penerapan lingkungan kerja yang baik diharapkan semangat kerja karyawan meningkat sehingga hal ini dapat mempengaruhi kinerja karyawan dan perusahaan. Hal ini sesuai dengan penelitian yang dilakukan oleh Gitonga (2015) dengan hasil penelitian yang menunjukkan bahwa lingkungan kerja memiliki pengaruh signifikan dan positif terhadap kinerja perusahaan pada kementerian pemerintah di Kenya. Badan Penanggulangan Bencana (BPBD) Provinsi Bali perlu memperhatikan lingkungan kerja para pegawainya, seperti peralatan dan perlengkapan kerja, pewarnaan ruangan, suhu udara yang memadai dan hubungan pegawai dengan atasan ataupun sebaliknya atasan dengan pegawai agar hubungan terjalin dengan baik sehingga pegawai merasa senang dan nyaman dalam melaksanakan pekerjaannya. Selain lingkungan kerja yang harus diperhatikan adalah komitmen organisasional.

Komitmen organisasi Badan Penanggulangan Bencana (BPBD) Provinsi Bali masih rendah. Rendahnya komitmen organisasi dalam hubungan keterlibatan pegawai yaitu instansi tidak memberikan kebebasan terhadap pegawai dalam menyampaikan pendapat dalam hal ini pegawai tidak dilibatkan dalam proses pengambilan kebijakan. Komitmen organisasi adalah keinginan kuat untuk tetap sebagai anggota organisasi tertentu, keinginan untuk berusaha keras sesuai dengan keinginan organisasi, serta keyakinan tertentu dan penerimaan nilai dan tujuan organisasi, dengan kata lain merupakan sikap yang merefleksikan loyalitas karyawan pada organisasi dan proses berkelanjutan dimana anggota organisasi mengekspresikan perhatiannya terhadap organisasi dan keberhasilan serta kemajuan yang berkelanjutan (Luthans, 2006).

Menurut Robbins (2018) menyatakan bahwa terdapat 3 macam dimensi komitmen organisasional yaitu: Komitmen Afektif, Komitmen Normatif, dan Komitmen Berkelanjutan. Komitmen Afektif yaitu perasaan emosional untuk organisasi dan keyakinan dalam nilai-nilainya. Komitmen Normatif yaitu perasaan 
wajib untuk tetap berada dalam organisasi karena memang harus begitu, tindakan tersebut merupakan hal benar yang harus dilakukan. Komitmen berkelanjutan yaitu nilai ekonomi yang dirasa dari bertahan dalam suatu organisasi bila dibandingkan dengan meninggalkan organisasi tersebut terdapat beberapa hasil penelitian yang melakukan penelitian tentang pengaruh komitmen organisasi terhadap kinerja karyawan. Menurut penelitian Hong (2012) yaitu komitmen organisasional berpengaruh positif dan signifikan terhadap kinerja pegawai. Menurut Ghorbanpour et al. (2014) yaitu komitmen organisasi memiliki pengaruh positif yang signifikan pada kinerja karyawan, komitmen normatif meninggalkan efek paling kuat pada rata-rata kinerja, dibandingkan dengan komitmen afektif dan komitmen berkelanjutan.

Dari latar belakang di atas maka akan diteliti lebih lanjut pengaruh keselamatan dan keselamatan kerja (K3), lingkungan kerja, serta komitmen organisasional terhadap kinerja pegawai dengan subjek penelitian yaitu pegawai Badan Penanggulangan Bencana Daerah (BPBD) Provinsi Bali.

Paramitadewi (2017) menyatakan bahwa kinerja adalah suatu hasil yang dicapai individu karyawan dalam melaksanakan tugas-tugas yang didasarkan atas kecakapan, pengalaman dan kesungguhan serta waktu menurut standar dan kriteria yang telah ditetapkan sebelumnya.

Keselamatan dan Kesehatan Kerja merupakan suatu kondisi dalam pekerjaan yang sehat dan aman baik itu bagi pekerjanya, perusahaan maupun bagi masyarakat dan lingkungan sekitar tempat kerja tersebut (Djatmiko, 2016).

Maslichah \& Hidayat (2017) mendefinisikan lingkungan kerja sebagai suatu atau keseluruhan dari komponen-komponen yang berhubungan dengan suatu lembaga, organisasi, atau perusahaan yang memiliki suatu pola yang tidak lepas dari lingkungan dimana lembaga, organisasi, atau perusahaan itu berada.

Sopiah (2013) menyatakan komitmen organisasional merupakan perspektif yang bersifat keperilakuan dimana komitmen diartikan sebagai perilaku yang konsisten dengan aktivitas (consistent lines of activity), sehingga semakin tinggi komitmen karyawan terhadap organisasi dapat meningkatkan rasa puas dari karyawan tersebut.

Lingkungan kerja merupakan sebuah tempat atau kantor yang menjadi faktor eksternal yang dapat mempengaruhi kinerja kerja pegawai. Lingkungan kerja yang baik dapat menciptakan hubungan kerja yang mengikat antara orang-orang yang ada di dalam lingkungannya. Lingkungan kerja adalah sesuatu yang ada dilingkungan para pekerja yang dapat mempengaruhi dirinya dalam menjalankan tugas seperti suasana nyaman dalam kantor maupun tugas lapangan, akses internet terjangkau, rekan kerja yang ramah, kebersihan tempat kerja, dan alat-alat perlengkapan kerja. Lingkungan kerja merupakan salah satu faktor yang mempunyai dampak positif terhadap kinerja pegawai (Nuraini, 2013:97). Lingkungan kerja yang baik dalam hal ini penyediaan sarana dan prasarana yang memadai atau buruk tidaknya ketersedian sarana dan prasarana penunjang dalam bekerja secara langsung ataupun tidak langsung akan dapat mempengaruhi semangat dan kegairahan karyawan dalam bekerja (Roharto \& Kasmir, 2017). Lingkungan kerja yang baik merupakan salah satu hal yang menyebabkan, menyalurkan, mendukung perilaku manusia supaya mau bekerja giat dan antusias 
mencapai hasil yang maksimal. Lingkungan kerja yang baik merupakan salah satu usaha pemeliharaan karyawan yang sangat penting untuk mempertahankan karyawan yang berkualitas dan memiliki kinerja tinggi.

Dengan penerapan lingkungan kerja yang baik diharapkan semangat kerja karyawan meningkat sehingga hal ini dapat mempengaruhi kinerja karyawan dan perusahaan. Hal ini sesuai dengan penelitian yang dilakukan oleh (Gitonga, 2015) dengan hasil penelitian yang menunjukkan bahwa lingkungan kerja memiliki pengaruh signifikan dan positif terhadap kinerja perusahaan pada kementerian pemerintah di Kenya. Badan Penanggulangan Bencana (BPBD) Provinsi Bali perlu memperhatikan lingkungan kerja para pegawainya, seperti peralatan dan perlengkapan kerja, pewarnaan ruangan, suhu udara yang memadai dan hubungan pegawai dengan atasan ataupun sebaliknya atasan dengan pegawai agar hubungan terjalin dengan baik sehingga pegawai merasa senang dan nyaman dalam melaksanakan pekerjaannya. Selain lingkungan kerja yang harus diperhatikan adalah komitmen organisasional.

Komitmen organisasi merupakan keyakinan yang menjadi pengikat adanya loyalitas, keterlibatan dalam pekerjaan, sehingga dapat tercapainya tujuan organisasi. Komitmen bertujuan untuk menguatkan kemauan dalam melaksanakan pekerjaan karyawan yang memiliki komitmen yang tinggi pada perusahaan akan memiliki kesadaran untuk bekerja lebih baik lagi sesuai dengan tanggung jawabnya karena karyawan merasa memiliki ikatan moral pada perusahaan. Oleh karena itu komitmen organisasi akan menimbulkan rasa ikut memiliki bagi karyawan terhadap organisasi. Menurut Asbah (2017) komitmen organisasi atau loyalitas pekerja adalah tingkatan dimana pekerja mengindentifikasi dengan organisasi dan ingin melanjutkan secara aktif berpartisinya.

Komitmen organisasi Badan Penanggulangan Bencana (BPBD) Provinsi Bali masih rendah. Rendahnya komitmen organisasi dalam hubungan keterlibatan pegawai yaitu instansi tidak memberikan kebebasan terhadap pegawai dalam menyampaikan pendapat dalam hal ini pegawai tidak dilibatkan dalam proses pengambilan kebijakan. Komitmen organisasi adalah keinginan kuat untuk tetap sebagai anggota organisasi tertentu, keinginan untuk berusaha keras sesuai dengan keinginan organisasi, serta keyakinan tertentu dan penerimaan nilai dan tujuan organisasi. Dengan kata lain merupakan sikap yang merefleksikan loyalitas karyawan pada organisasi dan proses berkelanjutan dimana anggota organisasi mengekspresikan perhatiannya terhadap organisasi dan keberhasilan serta kemajuan yang berkelanjutan (Luthans, 2006).

Menurut (Robbins, 2018) menyatakan bahwa terdapat 3 macam dimensi komitmen organisasional yaitu : Komitmen Afektif, Komitmen Normatif, dan Komitmen Berkelanjutan. Komitmen Afektif yaitu perasaan emosional untuk organisasi dan keyakinan dalam nilai-nilainya. Komitmen Normatif yaitu perasaan wajib untuk tetap berada dalam organisasi karena memang harus begitu, tindakan tersebut merupakan hal benar yang harus dilakukan.

Komitmen berkelanjutan yaitu nilai ekonomi yang dirasa dari bertahan dalam suatu organisasi bila dibandingkan dengan meninggalkan organisasi tersebut terdapat beberapa hasil penelitian yang melakukan penelitian tentang pengaruh komitmen organisasi terhadap kinerja karyawan seperti menurut penelitian (Hong, 
2012) yaitu komitmen organisasional berpengaruh positif dan signifikan terhadap kinerja pegawai. Menurut Ghorbanpour et al. (2014) yaitu komitmen organisasi memiliki pengaruh positif yang signifikan pada kinerja karyawan, komitmen normatif meninggalkan efek paling kuat pada rata-rata kinerja, dibandingkan dengan komitmen afektif dan komitmen berkelanjutan.

Keselamatan dan Kesehatan Kerja (K3) adalah suatu pemikiran dan upaya untuk menjamin keutuhan dan kesempurnaan baik jasmaniah maupun rohaniah tenaga kerja pada khususnya, dan manusia pada umumnya, hasil karya dan budaya untuk menuju masyarakat adil dan makmur (Alhamda \& Sriani, 2015). Keselamatan dan Kesehatan Kerja merupakan suatu kondisi dalam pekerjaan yang sehat dan aman baik itu bagi pekerjanya, perusahaan maupun bagi masyarakat dan lingkungan sekitar pabrik atau tempat kerja tersebut (Djatmiko, 2016).

Teori ini didukung dengan penelitian yang dilakukan Wibowo \& Widiyanto (2019) yang menyatakan keselamatan dan kesehatan kerja secara bersama-sama berpengaruh terhadap kinerja karyawan dan Putra \& Prasetya (2018) Program K3 berpengaruh signifikan terhadap kinerja karyawan. Widari et al. (2018) Hasil penelitian menunjukkan bahwa variabel bebas keselamatan kerja (X1) dan kesehatan kerja (X2) berpengaruh poisitif dan searah terhadap variabel kinerja pekerja (Y).

Penelitian yang dilakukan Chotimah, (2018) menyebutkan bahwa Keselamatan dan Kesehatan Kerja signifikan dan positif terkait dengan Kinerja Karyawan. Dalam penelitian ini ditemukan bahwa keselamatan dan kesehatan kerja berpengaruh positif dan signifikan terhadap kinerja karyawan. Dimana para karyawan di PT. PLN (Persero) Wilayah Sulutenggo Area Manado mempersepsikan bahwa program keselamatan kerja berdampak pada tingkat kinerja dari para karyawan.

$\mathrm{H}_{1}$ : Keselamatan dan Kesehatan Kerja berpengaruh positif dan signifikan terhadap Kinerja Karyawan.

Jayanti \& Syamsir (2018) mendefinisikan lingkungan kerja sebagai suatu atau keseluruhan dari komponen-komponen yang berhubungan dengan suatu lembaga, organisasi, atau perusahaan yang memiliki suatu pola yang tidak lepas dari lingkungan dimana lembaga, organisasi, atau perusahaan itu berada. Nitisemito (2011:13) mengemukakan bahwa lingkungan kerja adalah segala sesuatu yang ada di sekitar pekerja, yang dapat mempengaruhi seorang pekerja dalam menjalankan tugas-tugas yang diberikan.

Teori ini didukung dengan penelitian yang dilakukan Tobing \& Prihatini (2018) lingkungan kerja berpengaruh terhadap kinerja baik secara langsung maupun tidak langsung melalui disiplin kerja. Widodo (2018) lingkungan kerja secara bersama sama berpengaruh positif dan signifikan terhadap kinerja pada karyawan. Penelitian yang dilakukan Cahyani \& Mujiati (2019) lingkungan kerja berpengaruh positif dan signifikan terhadap semangat kerja guru di SMP Taman Sastra. Rahmawanti (2014) hasil penelitian ini menunjukkan bahwa berdasarkan analisis deskriptif menunjukkan bahwa mayoritas responden menyetujui lingkungan kerja fisik dan lingkungan kerja non fisik yang ada diperusahaan sudah baik sehingga kinerja karyawan meningkat. Hasil penelitian dan pembahasan (Jayanti \& Syamsir, 2018) menunjukan bahwa lingkungan kerja mempunyai 
pengaruh yang dominan terhadap kinerja perangkat nagari dalam pengelolaan keuangan nagari.

$\mathrm{H}_{2}$ : Lingkungan Kerja berpengaruh positif dan signifikan terhadap Kinerja Karyawan.

Sopiah (2013) menyatakan komitmen organisasional merupakan "perspektif yang bersifat keperilakuan dimana komitmen diartikan sebagai perilaku yang konsisten dengan aktivitas (consistent lines of activity)", sehingga semakin tinggi komitmen karyawan terhadap organisasi dapat meningkatkan rasa puas dari karyawan tersebut. Komitmen organisasional adalah kumpulan dari perasaan dan keyakinan bahwa orang-orang tersebut memiliki organisasi secara keseluruhan (George \& Jones, 2005). Menurut Putrana et al. (2016) berpendapat bahwa komitmen organisasional dapat dipakai untuk melihat perilaku kerja dan memprediksi aktivitas professional seorang karyawan pada organisasi.

Teori ini didukung dengan penelitian yang dilakukan Santi \& Rahyuda (2019) komitmen organisasional berpengaruh positif dan signifikan terhadap kinerja karyawan. Pranata \& Netra (2019) komitmen organisasional karyawan dan membuat kinerja karyawan yang disebabkan stres kerja dapat lebih rendah, sehingga karyawan Queen's Tandoor Seminyak lebih berkomitmen pada organisasi serta tidak berkeinginan untuk meninggalkan perusahaan. Gunawan \& Sriathi (2019) Komitmen organisasional berpengaruh positif terhadap kinerja karyawan yang artinya semakin baik komitmen organisasonal yang diterapkan pada perusahaan, maka semakin tinggi kinerja kerja karyawan untuk tetap berkomitmen di dalam perusahaan. Darmawan \& Wibawa (2019) komitmen organisasional berpengaruh positif secara parsial terhadap kinerja karyawan. Hasil penelitian ini menunjukkan bahwa Mahardika \& Wibawa (2019) komitmen organisasi memiliki pengaruh positif signifikan terhadap kinerja karyawan.

$\mathrm{H}_{3}$ : Komitmen Organisasional berpengaruh positif dan signifikan terhadap kinerja karyawan.

Pentingnya kinerja karyawan pada perusahaan membuat hal tersebut perlu diperhatikan, sehingga perlu diteliti faktor-faktor yang mempengaruhinya. Bangun (2012:231) mendefinisikan kinerja (performance) adalah hasil pekerjaan yang dicapai seseorang berdasarkan persyaratan-persyaratan pekerjaan (job reqruitment). Gibson et al. (2012) menyatakan bahwa kinerja adalah hasil perilaku yang diinginkan. Secara singkat, penekanan pada kinerja dapat diukur untuk jangka pendek dan jangka panjang, tergantung pada periode pencapaian tujuan ditempat kerja. Suatu pekerjaan mempunyai persyaratan tertentu untuk dapat dilakukan dalam mencapai tujuan yang disebut sebagai standard pekerjaan (job standard).

Kinerja menjadi tolak ukur yang dilakukan perusahaan untuk mengukur sejauh mana karyawan dapat mengemban tugas yang mereka emban dan bagaimana terdapat suatu kemajuan yang dialami perusahaan kedepannya. Menurut Malayu (2014:160) kinerja adalah suatu hasil kerja yang dicapai seseorang dalam melaksanakan tugas-tugasnya atas kecakapan, usaha dan kesempatan. Paramitadewi (2017) menyatakan bahwa kinerja adalah suatu hasil yang dicapai individu karyawan dalam melaksanakan tugas-tugas yang didasarkan atas kecakapan, pengalaman dan kesungguhan serta waktu menurut standar dan kriteria yang telah ditetapkan sebelumnya. 
Keselamatan dan Kesehatan Kerja (K3) adalah suatu pemikiran dan upaya untuk menjamin keutuhan dan kesempurnaan baik jasmaniah maupun rohaniah tenaga kerja pada khususnya, dan manusia pada umumnya, hasil karya dan budaya untuk menuju masyarakat adil dan makmur (Alhamda \& Sriani, 2015). Keselamatan dan Kesehatan Kerja merupakan suatu kondisi dalam pekerjaan yang sehat dan aman baik itu bagi pekerjanya, perusahaan maupun bagi masyarakat dan lingkungan sekitar pabrik atau tempat kerja tersebut (Djatmiko, 2016).

Dalam UU Nomor 1 Tahun 1970 Tentang Keselamatan Kerja disebutkan bahwa, Setiap tenaga kerja berhak mendapat perlindungan atas keselamatannya dalam melakukan pekerjaan untuk kesejahteraan hidup dan meningkatkan produksi serta produktivitas Nasional. Sedangkan dalam UU nomor 13 tahun 2003 pasal 86 dinyatakan bahwa, upaya keselamatan dan kesehatan kerja dimaksudkan untuk memberikan jaminan keselamatan dan untuk meningkatkan derajat kesehatan para pekerja/buruh dengan cara pencegahan kecelakaan dan penyakit akibat kerja, pengendalian bahaya di tempat kerja, promosi kesehatan, pengobatan, dan rehabilitasi.

Maslichah \& Hidayat (2017) mendefinisikan lingkungan kerja sebagai suatu atau keseluruhan dari komponen-komponen yang berhubungan dengan suatu lembaga, organisasi, atau perusahaan yang memiliki suatu pola yang tidak lepas dari lingkungan dimana lembaga, organisasi, atau perusahaan itu berada. Nitisemito (2011:13) mengemukakan bahwa lingkungan kerja adalah segala sesuatu yang ada di sekitar pekerja, yang dapat mempengaruhi seorang pekerja dalam menjalankan tugas-tugas yang diberikan. Sedangkan Rahmawanti (2014) mengemukakan lingkungan kerja adalah segala sesuatu yang ada di sekitar para pekerja yang dapat mempengaruhi dirinya dalam menjalankan tugas-tugas yang dibebankan. Lingkungan kerja secara langsung maupun tidak langsung akan memiliki dampak bagi perusahaan dan berpengaruh pada kinerja dari karyawan perusahaan. Terdukungnya lingkungan kerja yang baik akan membuat karyawan mampu melaksanakan pekerjaan dan tanggung jawabnya dengan baik (Maslichah \& Hidayat, 2017). Berdasarkan beberapa definisi tersebut dapat diseintesiskan bahwa lingkungan kerja adalah tempat dan kondisi dimana karyawan menyelesaikan pekerjaan mereka yang dapat mempengaruhi pengalaman kerja karyawan.

\section{METODE PENELITIAN}

Penelitian ini dilakukan pada BPBD Provinsi Bali, Renon Jalan D.I Panjaitan No.6 Panjer Denpasar Selatan. Lokasi ini dipilih karena terdapat permasalahan tentang keselamatan dan kesehatan kerja (K3), lingkungan kerja, serta komitmen organisasional terhadap kinerja karyawan.

Variabel dependen dalam penelitian ini yaitu Kinerja Karyawan yang dapat disimbolkan dengan $\mathrm{Y}$, sedangkan variabel independen dalam penelitian ini adalah keselamatan dan kesehatan kerja (K3), lingkungan kerja serta komitmen organisasional yang dapat disimbolkan dengan $\mathrm{X}_{1}, \mathrm{X}_{2}$, dan $\mathrm{X}_{3}$. Masing-masing variabel diukur menggunakan indikator sebagai berikut: 
Tabel 2.

Indikator Variabel Penelitian

\begin{tabular}{|c|c|c|}
\hline variabel & Indikator & Sumber \\
\hline Kinerja & 1. Prestasi kerja & \multirow{8}{*}{$\begin{array}{l}\text { Mangkunegara } \\
(2013: 13)\end{array}$} \\
\hline \multirow[t]{7}{*}{ Karyawan } & 2. Kejujuran & \\
\hline & 3. Tanggung jawab & \\
\hline & 4. Inisiatif & \\
\hline & 5. Kerjasama & \\
\hline & 6. Ketepatan waktu & \\
\hline & 7. Kecepatan kerja & \\
\hline & 8. Tingkat kesalahan kerja & \\
\hline \multirow{7}{*}{$\begin{array}{l}\text { Keselamatan } \\
\text { dan } \\
\text { kesehatan } \\
\text { kerja }\end{array}$} & 1. Penempatan benda & \multirow{7}{*}{$\begin{array}{l}\text { Hedianto et al. } \\
\text { (2014) }\end{array}$} \\
\hline & 2. Perlindungan pekerja & \\
\hline & 3. Penyediaan perlengkapan & \\
\hline & $\begin{array}{l}\text { 4. Penyediaan program sosialisasi pencegahan } \\
\text { kecelakaan }\end{array}$ & \\
\hline & 5. Lingkungan secara medis & \\
\hline & 6. Lingkungan kesehatan tenaga kerja & \\
\hline & 7. Pemeliharaan kesehatan & \\
\hline Lingkungan & 1. Penerangan di tempat kerja & \multirow[t]{7}{*}{ Fendy (2017) } \\
\hline \multirow[t]{6}{*}{ Kerja } & 2. Temeperatur ditempat kerja & \\
\hline & 3. Sirkulasi udara di tempat kerja & \\
\hline & 4. Kebisingan di tempat kerja & \\
\hline & 5. Keamanan di tempat kerja & \\
\hline & 6. Hubungan dengan rekan kerja & \\
\hline & 7. Fasilitas kerja & \\
\hline Komitmen & 1. Komitmen Afektif (affective commitment) & \multirow{3}{*}{$\begin{array}{l}\text { Meyer \& Allen, } \\
\text { (1991) }\end{array}$} \\
\hline \multirow[t]{2}{*}{ Organisasional } & 2. Komitmen berkelanjutan (continuance commitment) & \\
\hline & 3. Komitmen normatif (normative commitment) & \\
\hline
\end{tabular}

Sumber: Data diolah, 2020

Populasi dalam penelitian ini adalah seluruh pegawai pelaksana BPBD Provinsi Bali, berjumlah 50 orang. Teknik pengambilan sampel dilakukan dengan sampling jenuh, karena jumlah dari populasi tergolong kecil, sehingga seluruh populasi digunakan sebagai sampel. Metode pengumpulan data dalam penelitian ini menggunakan beberapa metode observasi, wawancara dan kuesioner. Instrumen penelitian yang digunakan dalam penelitian ini berupa angket atau kuisioner, yang dimaksudkan untuk menghasilkan data yang akurat yaitu dengan menggunakan skala Likert 5 poin.

Berdasarkan kerangka konsep penelitian dan hipotesis penelitian, analisis regresi liner berganda yang digunakan untuk menjawab permasalahan dalam penelitian ini. Model analisis ini digunakan dalam penelitian adalah analisis regresi linier berganda dengan menggunakan bantuan aplikasi SPSS (Statistical Package for Social Science). Adapun model analisis dari regresi berganda yang dimaksud adalah sebagai persamaan berikut.

$$
\mathrm{Y}=\mathrm{b}_{1} \mathrm{X}_{1}+\mathrm{b}_{2} \mathrm{X}_{2}+\mathrm{b}_{3} \mathrm{X}_{3+} \varepsilon
$$

Dimana :

$\mathrm{Y}=$ Kinerja karyawan

$\mathrm{b}_{1}-\mathrm{b}_{3} \quad=$ koefisien regresi dari masing-masing variabel

$\mathrm{X}_{1}=$ Keselamatan dan kesehatan kerja 
$\mathrm{X}_{2}=$ Lingkungan kerja

$\mathrm{X}_{3}=$ Komitmen Organisasional

$\varepsilon=$ Error

\section{HASIL DAN PEMBAHASAN}

Data pada Tabel 3. menunjukkan bahwa pegawai BPBD Provinsi Bali di dominasi oleh pegawai laki-laki. Bila dilihat dari umur responden, maka terlihat bahwa mayoritas pegawai BPBD Provinsi Bali adalah responden yang berusia 2030 tahun. Rentang usia ini dapat dikategorikan sebagai usia yang produktif dan diasumsikan memiliki semangat kerja yang tinggi, sehingga dapat melakukan pekerjaan dengan baik. Pengelompokan responden berdasarkan jenjang pendidikan menunjukkan bahwa mayoritas pegawai BPBD Provinsi Bali memiliki jenjang pendidikan pada jenjang Sarjana dengan jumlah sebanyak 21 orang atau sebesar 42 persen dari total pegawai. Seseorang yang sudah lulus pada jenjang Sarjana diasumsikan memiliki pemahaman dan kemampuan yang baik dalam bekerja. Distribusi berdasarkan masa kerja menunjukkan mayoritas pegawai BPBD Provinsi Bali sudah bekerja selama 1 hingga 10 tahun, dengan jumlah responden sebanyak 35 orang atau 70 persen dari total responden.

Tabel 3.

Karakteristik Responden

\begin{tabular}{|c|c|c|c|c|}
\hline No & Karakteristik & Klasifikasi & $\begin{array}{c}\text { Jumlah } \\
\text { Responden } \\
\text { (orang) }\end{array}$ & $\begin{array}{l}\text { Presentase } \\
\text { Responden } \\
(\%)\end{array}$ \\
\hline \multirow{4}{*}{1} & \multirow{4}{*}{ Umur } & 20-30 Tahun & 20 & 40 \\
\hline & & 31-40 Tahun & 13 & 26 \\
\hline & & 41-50 Tahun & 9 & 18 \\
\hline & & 51-60 Tahun & 8 & 16 \\
\hline \multirow{6}{*}{2} & \multirow{6}{*}{$\begin{array}{l}\text { Tingkat } \\
\text { Pendidikan }\end{array}$} & $\begin{array}{l}\text { 51-60 Tahun } \\
\text { Jumlah }\end{array}$ & 50 & 100 \\
\hline & & SMA/SMK Sederajat & 12 & 24 \\
\hline & & Diploma & 13 & 26 \\
\hline & & Sarjana (S1) & 21 & 42 \\
\hline & & \multirow{2}{*}{$\begin{array}{l}\text { Pascasarjana (S2) } \\
\text { Jumlah }\end{array}$} & 4 & 8 \\
\hline & & & 50 & 100 \\
\hline \multirow{3}{*}{3} & \multirow{3}{*}{ Masa Kerja } & 1-10 Tahun & 35 & 70 \\
\hline & & 11-20 Tahun & 7 & 14 \\
\hline & & \multirow{2}{*}{$\begin{array}{l}\text { 21-30 Tahun } \\
\text { Jumlah }\end{array}$} & 8 & 16 \\
\hline \multirow{4}{*}{4} & \multirow{4}{*}{ Jenis Kelamin } & & 50 & 100 \\
\hline & & Laki-Laki & 43 & 86 \\
\hline & & \multirow[t]{2}{*}{ Perempuan } & 7 & 14 \\
\hline & & & 50 & 100 \\
\hline
\end{tabular}

Sumber : Data Diolah, 2020

Hasil uji instrumen penelitian yang terdiri dari uji validitas dan uji reliabilitas, dalam penelitian ini dapat dilihat pada Tabel 5. Hasil uji validitas pada Tabel 5. menunjukkan bahwa seluruh instrumen penelitian yang digunakan untuk mengukur 
variabel keselamatan dan kesehatan kerja, lingkungan kerja, komitmen organisasional dan kinerja pegawai memiliki nilai koefisien korelasi dengan skor total seluruh item pernyataan lebih besar dari 0,30 dan memiliki koefisien Cronbach's Alpha lebih dari 0,70. Hal ini menunjukkan bahwa butir-butir pernyataan dalam instrument penelitian tersebut valid dan layak digunakan sebagai instrument penelitian.

Tabel 4.

Rekapitulasi Hasil Uji Validitas Instrumen Penelitian

\begin{tabular}{|c|c|c|c|c|}
\hline Variabel & Indikator & Koefisien Korelasi & Cronbadh's Alpha & Keterangan \\
\hline \multirow{8}{*}{$\begin{array}{l}\text { Kinerja pegawai } \\
(\mathrm{Y})\end{array}$} & $Y_{1}$ & 0,826 & \multirow{8}{*}{0,930} & Valid \\
\hline & $\mathrm{Y}_{2}$ & 0,791 & & Valid \\
\hline & $Y_{3}$ & 0,751 & & Valid \\
\hline & $\mathrm{Y}_{4}$ & 0,781 & & Valid \\
\hline & $\mathrm{Y}_{5}$ & 0,830 & & Valid \\
\hline & $Y_{6}$ & 0,887 & & Valid \\
\hline & $\mathrm{Y}_{7}$ & 0,776 & & Valid \\
\hline & $\mathrm{Y}_{8}$ & 0,928 & & Valid \\
\hline \multirow{8}{*}{$\begin{array}{l}\text { Keselamatan dan } \\
\text { kesehatan kerja } \\
\qquad\left(\mathrm{X}_{1}\right)\end{array}$} & $X_{1.1}$ & 0,798 & \multirow{8}{*}{0,929} & Valid \\
\hline & $\mathrm{X}_{1.2}$ & 0,823 & & Valid \\
\hline & $\mathrm{X}_{1.3}$ & 0,837 & & Valid \\
\hline & $\mathrm{X}_{1.4}$ & 0,862 & & Valid \\
\hline & $X_{1.5}$ & 0,794 & & Valid \\
\hline & $\mathrm{X}_{1.6}$ & 0,800 & & Valid \\
\hline & $\mathrm{X}_{1.7}$ & 0,814 & & Valid \\
\hline & $\mathrm{X}_{1.8}$ & 0,859 & & Valid \\
\hline \multirow{7}{*}{$\begin{array}{l}\text { Lingkungan kerja } \\
\qquad\left(\mathrm{X}_{2}\right)\end{array}$} & $\mathrm{X}_{2.1}$ & 0,892 & \multirow{7}{*}{0,888} & Valid \\
\hline & $\mathrm{X}_{2.2}$ & 0,772 & & Valid \\
\hline & $\mathrm{X}_{2.3}$ & 0,755 & & Valid \\
\hline & $\mathrm{X}_{2.4}$ & 0,832 & & Valid \\
\hline & $\mathrm{X}_{2.5}$ & 0,793 & & Valid \\
\hline & $\mathrm{X}_{2.6}$ & 0,695 & & Valid \\
\hline & $\mathrm{X}_{2.7}$ & 0,723 & & Valid \\
\hline \multirow{3}{*}{$\begin{array}{c}\text { Komitmen } \\
\text { organisasional }\left(\mathrm{X}_{3}\right)\end{array}$} & $\mathrm{X}_{3.1}$ & 0,849 & \multirow{3}{*}{0,861} & Valid \\
\hline & $X_{3.2}$ & 0,904 & & Valid \\
\hline & $\mathrm{X}_{3.3}$ & 0,903 & & Valid \\
\hline
\end{tabular}

Sumber : Data primer diolah, 2020

Tabel 5.

Rangkuman Hasil Uji Asumsi Klasik

\begin{tabular}{|c|c|c|c|c|c|}
\hline \multirow{2}{*}{\multicolumn{2}{|c|}{ Hasil Uji Normalitas }} & \multirow[t]{2}{*}{ Variabel } & \multicolumn{2}{|c|}{$\begin{array}{c}\text { Hasil Uji } \\
\text { Multikolinieritas }\end{array}$} & \multirow{2}{*}{$\begin{array}{c}\text { Hasil Uji } \\
\text { Heteroskedastisitas } \\
\text { Signifikansi } \\
\end{array}$} \\
\hline & & & Tolerance & VIF & \\
\hline $\mathrm{N}$ & 50 & $\begin{array}{c}\text { Keselamatan dan } \\
\text { kesehatan kerja }\left(\mathrm{X}_{1}\right)\end{array}$ & 0,240 & 4,159 & 0,580 \\
\hline $\begin{array}{l}\text { Kolmogorov- } \\
\text { Smirnov Z }\end{array}$ & 0,683 & $\begin{array}{l}\text { Lingkungan kerja } \\
\qquad\left(\mathrm{X}_{2}\right)\end{array}$ & 0,305 & 3,276 & 0,134 \\
\hline $\begin{array}{l}\text { Asymp. Sig. } \\
\text { (2-tailed) }\end{array}$ & 0,739 & $\begin{array}{c}\text { Komitmen } \\
\text { organisasional }\left(\mathrm{X}_{3}\right)\end{array}$ & 0,339 & 2,948 & 0,276 \\
\hline
\end{tabular}


Tabel 5. menunjukkan nilai tolerance setiap variabel lebih dari $10 \%$ dan nilai VIF kurang dari 10, sehingga dinyatakan data lolos uji multikolinieritas, sehingga data layak dilakukan lebih lanjut.

Tabel 6.

Hasil Analisis Regresi Linier Berganda

\begin{tabular}{|c|c|c|c|c|c|}
\hline Variabel & \multicolumn{2}{|c|}{$\begin{array}{c}\text { Unstandardized } \\
\text { Coefficients } \\
\text { Std. }\end{array}$} & $\begin{array}{c}\text { Standardized } \\
\text { Coefficients } \\
\text { Beta }\end{array}$ & t hitung & $\begin{array}{l}\text { Sig. } \\
\text { uji t }\end{array}$ \\
\hline (Constant) & 0,443 & 0,261 & & 1,699 & 0,096 \\
\hline $\begin{array}{l}\text { Keselamatan dan } \\
\text { kesehatan kerja }\left(\mathrm{X}_{1}\right)\end{array}$ & 0,294 & 0,134 & 0,283 & 2,202 & 0,033 \\
\hline Lingkungan kerja $\left(\mathrm{X}_{2}\right)$ & 0,381 & 0,112 & 0,388 & 3,396 & 0,001 \\
\hline Komitmen organisasi $\left(\mathrm{X}_{3}\right)$ & 0,246 & 0,088 & 0,305 & 2,812 & 0,007 \\
\hline R Square & 0,817 & & & & \\
\hline Adjusted R Square & 0,805 & & & & \\
\hline F Statistik & 68,407 & & & & \\
\hline Signifikansi Uji F & 0,000 & & & & \\
\hline
\end{tabular}

Nilai R Square sebesar 0,817 mempunyai arti bahwa sebesar $81,7 \%$ variasi kinerja pegawai BPBD Provinsi Bali dipengaruhi oleh variasi keselamatan dan kesehatan kerja, lingkungan kerja, dan komitmen organisasional, sedangkan sisanya sebesar $18,3 \%$ dijelaskan oleh faktor lain yang tidak dimasukkan ke dalam model.

Nilai $F_{\text {hitung }}$ sebesar 68,407 dengan nilai signifikansi 0,000<0,05, maka dapat disimpulkan bahwa pada kelompok yang diuji memiliki perbedaan yang nyata (signifikan). Hasil ini mempunyai arti bahwa secara simultan keselamatan dan kesehatan kerja, lingkungan kerja, dan komitmen organisasional berpengaruh signifikan terhadap kinerja pegawai BPBD Provinsi Bali.

Berdasarkan hasil analisis pengaruh keselamatan dan kesehatan kerja terhadap kinerja pegawai diperoleh nilai signifikasi sebesar 0,033 dengan nilai koefisien regresi positif sebesar 0,294 Nilai Signifikansi $0,033<0,05$ mengindikasikan bahwa $\mathrm{H}_{1}$ diterima. Hasil ini mempunyai arti bahwa keselamatan dan kesehatan kerja berpengaruh positif dan signifikan terhadap kinerja pegawai pada BPBD Provinsi Bali. Hal ini memiliki makna bahwa semakin tinggi implementasi keselamatan dan kesehatan kerja di BPBD Provinsi Bali, maka dampak kecelakaan dan penyakit kerja pegawai akan dapat diminimalisir, sehingga kinerja yang dihasilkan akan semakin tinggi. Begitu pula sebaliknya, semakin rendah implementasi program keselamatan dan kesehatan kerja di BPBD Provinsi Bali maka semakin kinerja pegawai pada BPBD Provinsi Bali akan semakin menurun. Hasil penelitian ini sesuai dengan temuan Chotimah (2018) yang memperoleh hasil bahwa keselamatan dan kesehatan kerja berpengaruh positif dan signifikan terhadap kinerja karyawan, yaitu pelaksanaan program keselamatan kerja berdampak pada meningkatnya kinerja dari para karyawan. Hasil ini juga mendukung temuan penelitian Wibowo \& Widiyanto (2019), Putra \& Prasetya (2018), Widari et al. (2018), Djatmiko (2016) yang menyebutkan bahwa Program 
K3 berpengaruh signifikan terhadap kinerja karyawan. Hal ini berarti semakin baik keselamatan dan kesehatan kerja yang diterapkan oleh suatu perusahaan maka akan semakin baik pula kinerja pegawainya.

Berdasarkan hasil analisis pengaruh lingkungan kerja terhadap kinerja pegawai diperoleh nilai signifikansi sebesar 0,001 dengan nilai koefisien regresi yang positif sebesar 0,381 . Nilai Signifikansi $0,001<0,050$, maka mengindikasikan bahwa $\mathrm{H}_{2}$ diterima. Hasil ini mempunyai arti bahwa Lingkungan kerja berpengaruh positif dan signifikan terhadap kinerja pegawai pada BPBD Provinsi Bali. Hal ini memiliki makna bahwa semakin baik kondisi lingkungan kerja kerja pada BPBD Provinsi Bali, maka akan semakin meningkatkan kinerja pegawai. Begitu pula sebaliknya, semakin buruk kondisi lingkungan kerja kerja di BPBD Provinsi Bali maka kinerja pegawai pada BPBD Provinsi Bali akan semakin menurun. Penelitian ini sesuai dengan temuan Maslichah \& Hidayat (2017) yang menemukan hasil bahwa lingkungan kerja mempunyai pengaruh yang dominan terhadap kinerja pegawai dalam organisasi. Hasil penelitian ini juga sesuai dengan temuan penelitian Tobing \& Prihatini (2018), Widodo (2018), Cahyani \& Mujiati (2019) dan Rahmawanti (2014) yang memperoleh hasil bahwa lingkungan kerja berpengaruh positif dan signifikan terhadap kinerja pegawai. Semakin baik lingkungan kerja maka semakin tinggi pula tingkat kinerja pegawai. Maka dari itu lingkungan kerja sangat mempengaruhi kinerja pegawai. Sebab, lingkungan kerja adalah segala sesuatu yang ada di sekitar pekerja, yang dapat mempengaruhi seorang pekerja dalam menjalankan tugas-tugas yang diberikan.

Berdasarkan hasil analisis pengaruh komitmen organisasional terhadap kinerja pegawai diperoleh nilai signifikansi sebesar 0,007 dengan nilai koefisien regresi positif sebesar 0,246. Nilai signifikansi 0,007 < 0,05 mengindikasikan bahwa $\mathrm{H}_{3}$ diterima. Hasil ini mempunyai arti bahwa komitmen organisasional berpengaruh positif dan signifikan terhadap kinerja pegawai pada BPBD Provinsi Bali. Hal ini memiliki makna bahwa semakin tinggi komitmen organisasional yang dimiliki pegawai BPBD Provinsi Bali, maka akan semakin tinggi pula sikap loyalitas yang ditunjukkan oleh pegawai, sehingga kinerja yang dihasilkan akan semakin meningkat. Begitu pula sebaliknya, semakin rendah komitmen organisasional yang dimiliki pegawai BPBD Provinsi Bali maka semakin rendah kinerja pegawai pada organisasi tersebut. Penelitian ini sesuai dengan hasil penelitian Mahardika \& Wibawa (2019) yang menemukan hasil bahwa komitmen organisasi memiliki pengaruh positif signifikan terhadap kinerja karyawan. Hal ini berarti dengan rasa komitmen yang tinggi maka kinerja pegawai akan semakin meningkat. Hasil penelitian ini juga sesuai dengan temuan penelitian Sopiah (2013), Putrana et al. (2016), Santi \& Rahyuda (2019), Pranata \& Netra (2019), Gunawan \& Sriathi (2019) dan Darmawan \& Wibawa (2019) yang menyatakan bahwa semakin baik komitmen organisasonal yang diterapkan pada perusahaan, maka semakin tinggi kinerja karyawan untuk tetap berkomitmen di dalam perusahaan

Implikasi dari hasil penelitian yang didapat diharapkan mampu menjadikan tambahan pengetahuan, referensi dan bahan pertimbangan bagi pihak manajemen BPBD Provinsi Bali dalam proses pengambilan keputusan dan penetapan kebijakan perusahaan untuk meningkatkan kinerja pegawainya. Program keselamatan dan 
kesehatan kerja yang efektif perlu ditingkatkan, sehingga kinerja pegawai akan meningkat. Selain itu, lingkungan kerja juga menjadi salah satu faktor yang sangat menentukan kinerja pegawai, karena dapat menjadi sumber motivasi pegawai untuk bekerja lebih baik bagi perusahaan. Kemudian komitmen organisasi pegawai juga harus mampu ditingkatkan dengan baik, agar pegawai mampu bekerja dengan baik. Jika keselamatan dan kesehatan kerja, lingkungan kerja dan komitmen organisasional ini mampu diterapkan dan dijalankan dengan baik, maka kinerja pegawai akan meningkat yang nantinya akan memberikan dampak yang sangat besar pada kinerja pegawai yang semakin membaik dan meningkat bagi BPBD Provinsi Bali.

\section{SIMPULAN}

Berdasarkan hasil analisis penelitian maka dapat disimpulkan Keselamatan dan kesehatan kerja berpengaruh positif dan signifikan terhadap kinerja pegawai. Hal ini berarti bahwa semakin baik pelaksanaan program keselamatan dan kesehatan kerja yang diterapkan oleh pegawai maka akan kinerja pegawai pada BPBD Provinsi Bali akan semakin meningkat. Lingkungan kerja berpengaruh positif dan signifikan terhadap kinerja pegawai. Hal ini berarti bahwa semakin baik kondisi lingkungan kerja pada BPBD Provinsi Bali, maka akan semakin meningkatkan kinerja pegawai. Komitmen organisasional berpengaruh positif dan signifikan terhadap kinerja pegawai. Hal ini berarti bahwa semakin tinggi komitmen organisasional yang dimiliki pegawai BPBD Provinsi Bali, maka akan semakin tinggi pula kinerja yang ditunjukkan oleh pegawai.

Berdasarkan hasil penyebaran kuesioner, indikator yang memperoleh nilai rata-rata terendah adalah indikator kecepatan kerja. Oleh karena itu, dalam upaya meningkatkan kinerja pegawai, maka pihak manajemen BPBD Provinsi Bali sebaiknya rutin memberikan pelatihan tugas bagi pegawainya, agar secara menyeluruh pegawai mampu mengerjakan tugas lebih cepat. Berdasarkan hasil penyebaran kuesioner, indikator yang memperoleh nilai rata-rata terendah adalah penyediaan program sosialisasi. Oleh karena itu, dalam upaya meningkatkan pelaksanaan program keselamatan dan kesehatan kerja ke arah yang lebih baik, maka pimpinan BPBD Provinsi Bali sebaiknya meningkatkan program sosialisasi pencegahan kecelakaan secara rutin bagi pegawainya. Berdasarkan hasil penyebaran kuesioner, indikator yang memperoleh penilaian terendah dari responden adalah indikator keamanan di tempat kerja. Oleh karena itu, dalam upaya meningkatkan lingkungan kerja ke arah yang lebih baik, maka BPBD Provinsi Bali sebaiknya meningkatkan kondisi keamanan diruang kerja agar lebih terjamin dan tidak akan pernah terjadi kehilangan barang, agar pegawai merasa lebih nyaman untuk bekerja dengan kondisi lingkungan kerja yang aman.

Berdasarkan hasil penyebaran kuesioner, indikator yang memperoleh nilai rata-rata terendah adalah indikator komitmen afektif. Oleh karena itu, dalam upaya meningkatkan komitmen organisasional menjadi lebih baik lagi, maka BPBD Provinsi Bali diharapkan dapat meningkatkan komitmen afektif pada pegawainya, dengan cara sering mengadakan kegiatan organisasi dengan kerjasama tim yang menyenangkan sehingga dapat membentuk hubungan emosional pegawai terhadap kegiatan organisasi tersebut. 


\section{REFERENSI}

Akpan, E. I. (2011). Effective Safety and Health Management Policy for Improved Performance of Organizations in Africa. International Journal of Business and Management, 6(3), 159-165.

Alhamda, S., \& Sriani, Y. (2015). Buku Ajar Ilmu Kesehatan Masyarakat (IKM). Jakarta: Deepublish.

Almeida, V. A. de, Arif, M., \& Tridayanti, H. (2019). The Effect of Leadership Style and Work Environment on Employee Performance of Bnctl Branch Banks (Banco Nacional De Comercio De Timor-Leste). International Journal of Entrepreneurship And Business Development, 3(1). https://doi.org/https://doi.org/10.29138/ijebd.v3i1.951

Asbah, N. (2017). Pengaruh Pengembangan Karir, Komitmen Organisasi dan Motivasi Terhadap Kinerja Karyawan Pada Perusahaan Daerah Air Minum Tirtanadi Kota Medan.

Sub Bagian Umum Badan Penanggulangan Bencana Daerah (BPBD) Provinsi Bali. (2019). Rekapitulasi Bencana yang Ditangani BPBD Provinsi Bali Tahun 2018.

Bangun, W. (2012). Manajemen Sumber Daya Manusia. Jakarta: Erlangga.

Cahyani, N. M. D. M., \& Mujiati, N. W. (2019). Pengaruh Lingkungan Kerja, Motivasi Dan Kompensasi Terhadap Semangat Kerja. E-Jurnal Manajemen, 8(5), 3193-3219.

https://doi.org/https://doi.org/10.24843/EJMUNUD.2019.v08.i05.p22.

Chotimah, C. (2018). Pengaruh Kompetensi Dan K3 (Keselamatan Dan Kesehatan Kerja) Terhadap Kinerja Karyawan Pada Pt. Lotus Indah Textile Industries Bagian Winding Di Nganjuk. Jurnal Ilmu Manajemen, 6(2).

Darmanegara, I. (2013). Effect of Spiritual Intelligence and Asta Brata Leadership The Culture of Tri Hita Karana and Employment Performance. IOSR Journal of Business and Management (IOSR-JBM), II(2), 05-12.

Darmawan, I. G. W., \& Wibawa, I. M. A. (2019). Pengaruh Kompensasi Finansial, Lingkungan Kerja Non Fisik, Dan Komitmen Organisasional Terhadap Semangat Kerja Karyawan. E-Jurnal Manajemen, 8(8), 2019.

Djatmiko, R. D. (2016). Keselamatan dan Kesehatan Kerja. Yogyakarta: deepublish.

Fendy. (2017). Pengaruh Disiplin Kerja dan Lingkungan Kerja Terhadap Kinerja Karyawan Pada PT Jadin Pratama. Repository Universitas Unggul.

George, J. M., \& Jones, G. R. (2005). Understanding and managing organizational behavior (4th ed.). New Jersey: Pearson-Prentice Hal.

Ghorbanpour, Z., D.D., H., \& Heyrani, F. (2014). Investigating the Effect of Organization Commitment on Performance of Auditors in the Community of Certified Accountants. Interdisciplinary Journal Of Contemporary Research In Business, 5(10), 199-209. 
Gibson, J. L., Donnelly Jr, J. H., Ivancevich, J. M., \& Konopaske, R. (2012). Organizationa Behavior, Structure, Processes (14, Ed.). New York: McGraw Hill.

Gitonga, L. (2015). Influence of Work Environment on Organizational Performance in Government Ministries in Kenya. Jomo Kenyatta University of Agriculture and Technology (JKUAT), 2(83), 1043-1071.

Gunawan, N. M., \& Sriathi, A. A. A. (2019). Stres Kerja, Komitmen Organisasional, Dan Gaya Kepemimpinan Terhadap Kepuasan Kerja Karyawan. EJurnal Manajemen, 8(9), 5344-5371.

Handoko, T. H. (2017). Manajemen. Yogyakarta: BPFE.

Hedianto, B. R., \& Iqbal, M. D. M. M. (2014). Pengaruh Keselamatan dan Kesehatan Kerja (K3)terhadap Motivasi Kerja Karwyawan (Studi pada Karyawan bagian Drilling \& Oilfield Services PT Elnusa Tbk. Jakarta). Jurnal Administrasi Bisnis S1 Universitas Brawijaya, 10(1), 81925.

Hong, H. Y. D. (2012). The Mediating Effect of Organizational Commitment on Leadership Type and Job Performance. The Journal of Human Resource and Adult Learning, 8(2), 5118-5138.

Jayanti, N. P. ., \& Syamsir, S. (2018). Pengaruh Lingkungan Kerja Terhadap Kinerja Perangkat Nagari Dalam Pengelolaan Keuangan Nagari Di Kabupaten Tanah Datar. JESS (Journal of Education on Social Science), 2(1), 35-46.

Katua, N. T., Makulu, E., \& Gachunga, H. G. (2014). Effect Of Reward And Compensation Strategies On The Performance Of Commercial Banks In Kenya. International Journal of Education and Research, 2(1), 1-20.

Kautsar, I. Al, S, B. S., \& Musadieq, M. Al. (2013). Pengaruh Keselamatan Dan Kesehatan Kerja Terhadap Kinerja Karyawan (Studi pada Karyawan Tetap Bagian Produksi PR.Sejahtera Abadi Malang). Jurnal Administrasi Bisnis S1 Universitas Brawijaya, 6(2), 78070.

Luthans, F. (2006). Perilaku organisasi (10th ed.). Yogyakarta: Andi.

Machabe, A. P., \& Indermun, V. (2013). An Overview Of The Occupational Health And Safety Act: A Theoretical And Practical Global Perspective. Arabian Journal of Business and Management Review, 3(5), 13-33.

Maduka, C. E., \& Okafor, O. (2014). Effect of Motivation on Employee Productivity: A Study of Manufacturing Companies in Nnewi. International Journal of Managerial Studies and Research (IJMSR), 2(7), 60-68.

Mahardika, I. N. B. P., \& Wibawa, I. M. A. (2019). Pengaruh Budaya Organisasi Kepuasan Kerja Dan Komitmen Organisasional Terhadap Organizational Citizenship Behavior Pada Karyawan. E-Jurnal Manajemen, 8(1), 7340 - 7370.

Malayu, H. S. . (2014). Manajemen Sumber Daya Manusia. Jakarta: Bumi Aksara. Mangkunegara. (2013). Manajemen Sumber Daya Manusia Perusahaan (1st ed.). Bandung: PT. Remaja Rosdakarya.

Maslichah, N. I., \& Hidayat, K. (2017). Pengaruh Work-life Balance dan 
Lingkungan Kerja Terhadap Kepuasan Kerja Karyawan. Jurnal Administrasi Bisnis (JAB), 49(1), 60-68.

Meyer, J. P., \& Allen, N. J. (1991). A three component conceptualization of organizational commit-ment. Human Resource Management Review 1, 61-89.

Nitisemito, A. S. (2011). Manajemen Personalia (Manajemen Sumber Daya Manusia) (5th ed.). Jakarta: Ghalia.

Nuraini, T. (2013). Manajemen Sumber Daya Manusia. Pekanbaru: Yayasan Aini Syam.

Paramitadewi, K. F. (2017). Pengaruh Beban Kerja Dan Kompensasi Terhadap Kinerja Pegawai Sekretariat Pemerintah Daerah Kabupaten Tabanan. E-Jurnal Manajemen, 6(6).

Pranata, G. D., \& Netra, I. G. S. K. (2019). Pengaruh Stres Kerja Terhadap Turnover Intention Melalui Mediasi Komitmen Organisasional Pada Restoran Queen's Tandoor Seminyak. Jurnal Manajemen, 8(6), 3531-3559.

Priarso, M. T. (2018). The Effect Of Transformational Leadership Style, Work Motivation, And Work Environment On Employee Performance That In Mediation By Job Satisfaction Variables In Pt. Gynura Consulindo. Trijurnal: Portal Jurnal Online Universitas Trisakti, 18(2).

Putra, R. E., \& Prasetya, A. (2018). Pengaruh Program Keselamatan Dan Kesehatan Kerja Terhadap Motivasi Kerja Dan Kinerja Karyawan. Jurnal Administrasi Bisnis $(J A B), 56(2)$.

Putrana, Y., Fathoni, A., \& Warso, M. M. (2016). Pengaruh kepuasan kerja dan komitmen organisasi terhadap organizational citizenship behavior dalam meningkatkan kinerja karyawan pada PT. Gelora Persada Mediatama Semarang. Journal of Management, 2(2), 1-14.

Rahmawanti, N. P. (2014). Pengaruh Lingkungan Kerja Terhadap Kinerja Karyawan (Studi pada Karyawan Kantor Pelayanan Pajak Pratama Malang Utara). Jurnal Administrasi Bisnis (JAB), 8(2).

Rivai, V., \& Sagala, E. J. (2014). Manajemen Sumber Daya Manusia untuk Perusahaan: Dari Teori ke Praktik (Edisi 3). Jakarta: Rajawali Pers.

Robbins, S. P. dan T. A. J. (2018). Perilaku Organisasi (12th ed.). Jakarta: Salemba Empat.

Roharto, T., \& Kasmir. (2017). Pengaruh Keselamatan dan Kesehatan Kerja (K3), Lingkungan Kerja, dan Pelatihan terhadap Kinerja pada PT Pelabuhan Indosnesia II (Persero) Jakarta (Studi Kasus pada Proyek Pengerukan Pembangunan TPK Kalibaru). Jurnal SWOT, VII(3), 629-645.

Santi, K. S. P., \& Rahyuda, A. G. (2019). Peran Komitmen Organisasional Memediasi Pengaruh Kepemimpinan Transformasional Terhadap OCB. E-Jurnal Manajemen, 8(7), 4239-4267.

Sopiah. (2013). The Effect of Compensation Toward Job Satisfaction and Job 
Perfomance of Outsourcing Employees of Syariah Banks in Malang Indonesia. International Learning and Development, 3(2), 77-91.

Sugiyono, H. (2017). Manajemen Sumber Daya Manusia (7th ed.). Yogyakarta: STIE YKPN.

Supriyadi. (2010). Pengaruh keselamatan kerja terhadap kinerja karyawan pada CV. Sriwijaya utama di Bandar lampung. Jurnal Sains Dan Inovasi, 6(1), 15-21.

Tobing, D. L. P. D. S. K., \& Prihatini, D. (2018). Pengaruh Motivasi Kerja Dan Lingkungan Kerja Terhadap Kepuasan Kerja Disiplin Kerja Dan Kinerja Karyawan Pt. Kereta Api Indonesia (Persero) Daop Ix Jember. Jurnal Bisnis Dan Manajemen, 12(2), $204-211$.

Tsenawatme, A. (2013). Pengaruh Keselamatan Dan Kesehatan Kerja Terhadap Kinerja Karyawan (Studi Pada Departemen Social Outreach \& Local Development (SLD) Dan Community Relations (CR) PT.Freeport Indonesia). Jurnal Administrasi Publik UNSRAT.

Wibowo, E., \& Utomo, H. (2016). Pengaruh Keselamatan Kerja dan Kesehatan Kerja terhadap Kinerja dengan Kepuasan Kerja sebagai Variabel Intervening (Studi Kasus pada Karyawan Bagian Produksi Unit Serbuk Effervescent PT Sido Muncul Semarang). Among Makarti, 9(17), 38-59.

Wibowo, P., \& Widiyanto, G. (2019). Pengaruh Keselamatan Dan Kesehatan Kerja Dan Lingkungan Kerja Terhadap Kinerja Karyawan Bagian Produksi Pada Perusahaan Tom's Silver Yogyakarta. Jurnal Ekonomi Dan Bisnis, 17(2).

Widari, L. A., Zulfhazli, \& A., O. M. R. (2018). Terhadap Kinerja Pekerja Konstruksi (Studi kasus Proyek The Manhattan Mall and Condominium). Teras Jurnal, 8(1).

Widodo, T. W. (2018). Pengaruh Kepuasan Kerja dan Lingkungan Kerja terhadap Kinerja Karyawan Bagian Perbendaharaan dan Mobilisasi Dana RSUP Dr Sardjito. Jurnal Ekobis Dewantara, 1(9). 